\title{
THE INACTIVATION OF PEPSIN BY SODIUM CHLORID: ITS CLINICAL SIGNIFICANCE*
}

\author{
WALTER W. HAMBURGER, M.D. \\ CHICAGO
}

The problem of the etiology of ulcer of the stomach has recently been approached from the point of view of that older problem-the nondigestibility of the stomach by its own digestive juice. For instance, Frentzel, ${ }^{1}$ in 1891, and Katzenstein, ${ }^{2}$ in 1908, showed that living stomach and duodenum implanted in the stomach were not influenced in any way, while small intestine and spleen under similar conditions were promptly digested. Katzenstein believed that the resistance of the stomach and duodenum to peptic digestion was due to the presence in the stomach wall of a specific inhibiting body-antipepsin.

In a more recent contribution, Katzenstein, ${ }^{3}$ by reducing the antipepsin content of the stomach and blood (by methods not altogether clear), succeeded in producing chronic experimental ulcers in dogs' stomachs. He concluded that gastric ulcer is a sequence to a local injury of the stomach wall, whereby the normal balance between gastric juice pepsin, and gastric wall antipepsin, is disturbed.

While these conceptions are interesting and original, considerable doubt has arisen as to the validity and nature of this so-called antipepsin. Carl Oppenheimer, in his "Die Fermente und ihre Wirkungen," " after a critical survey of all available evidence, concludes:

Im Allgemeinen ist es wohl wahrscheinlich dass hier keine echten Antikörper im Sinne der Immunitätslehre vorliegen. Es sind eher negative Katalysatoren.

He points out that this antipepsin is thermostabile, that it does not completely inhibit pepsin action, and that similar "antipepsins" may be found in extracts of yeast, molds and bacteria.

During the progress of research ${ }^{5}$ on so-called antipepsin of the blood serum in 1911, I was able to show, in association with Dr. Jobling, that blood serum is capable of permanently binding pepsin and preventing it from digesting protein. We concluded from a con-

\footnotetext{
* Submitted for publication May 2, 1915.

* From the Morris Institute for Medical Research and the Michael Reese Hospital, Chicago.

1. Frentzel (quoted by Kathe): Berl. klin. Wchnschr., 1908, xlv, 2136.

2. Katzenstein: Berl. klin. Wchnschr., 1908, xlv, 1749.

3. Katzenstein: Arch. f. klin. Chirurg., 1913, ci, 1.

4. Oppenheimer, C.: "Die Fermente und ihre Wirkungen," Ed. 3, Leipzig, 1910.

5. Hamburger: Jour. Exper. Med., 1911, xiv, 535.
} 
siderable series of biochemical experiments that this inactivation of pepsin was not due to a specific antibody of the blood serum, but was due to a quantitative nonspecific pepsin deviation, similar to the deviation described for other ferments, notably trypsin.

In the development of a suitable technic for this work, a most interesting fact was observed, notably, that under certain conditions, sodium chlorid, used as physiological salt solution, would completely prevent pepsin from digesting protein. The conditions under which this inhibition occurred are simply that the ferment be made up in aqueous solution, with all trace of hydrochloric acid removed. If a faint trace of acid be present, or be added before sodium chlorid solution, no inhibition occurs. Moreover, hydrochloric acid added

TABLE 1.-Inhibition of Pepsin by Sodium Chlorid

\begin{tabular}{|c|c|c|c|c|c|c|c|}
\hline Tube* & $\begin{array}{c}0.85 \mathrm{Pct} . \\
\mathrm{NaCl} \\
\text { c.c. }\end{array}$ & $\begin{array}{l}\text { Water } \\
\text { c.c. }\end{array}$ & $\begin{array}{l}\mathrm{N} / 10 \\
\mathrm{HCl} \\
\text { c.c. }\end{array}$ & 10 Minutes & 60 Minutes & 18 Hours & 24 Hours \\
\hline $\begin{array}{l}1 \\
2 \\
3 \\
4 \\
5 \\
6 \\
7 \\
8 \\
9\end{array}$ & $\begin{array}{l}2.5 \\
2.5 \\
2.5 \\
\cdots \\
\cdots \\
\cdots \\
\cdots \\
\cdots \\
\cdots\end{array}$ & $\begin{array}{l}\cdots \\
\cdots \\
2.5 \\
2.5 \\
2.5 \\
\cdots \\
\cdots \\
\cdots\end{array}$ & $\begin{array}{l}0.5 \\
1.0 \\
5.0 \\
0.5 \\
1.0 \\
5.0 \\
0.5 \\
5.0 \\
1.0\end{array}$ & $\begin{array}{l}0 \\
0 \\
0 \\
0 \\
0 \\
0 \\
0 \\
0 \\
0\end{array}$ & $\begin{array}{c}0 \\
0 \\
\text { Trace? } \\
+ \\
+ \\
+ \\
+ \\
+ \\
+\end{array}$ & $\begin{array}{c}0 \\
0 \\
0 \\
+++ \\
+++ \\
++++ \\
+++ \\
++++ \\
++++\end{array}$ & $\begin{array}{c}0 \\
0 \\
0 \\
++++ \\
++++ \\
++++ \\
++++ \\
++++ \\
++++\end{array}$ \\
\hline
\end{tabular}

* In each tube was placed carmin fibrin and $0.0001 \mathrm{gm}$. pepsin in 1 c.c. water. All tubes were incubated for thirty minutes.

Sodium chlorid ( 2.5 c.c. of 0.85 per cent. solution) prevents pepsin in solution in water from digesting carmin fibrin; the addition of $\mathrm{N} / 10$ hydrochloric acid in excess does not reactivate ferment. Control tubes alone and with water show complete digestion in twenty-four hours. $0=$ no digestion;,,++++++ , partial digestion; $++++=$ complete digestion.

after sodium chlorid inhibition fails to reactivate the pepsin, the inhibition remaining permanent-inactivation. (Tables 1 and 2 will make these relations clear.) Under such conditions, sodium chlorid would likewise be considered an antipepsin.

It was our belief that this inactivation of pepsin (when in aqueous solution) by normal serum and by sodium chlorid were important factors in the action of so-called antipepsin, and that such inactivation was responsible for most, if not all, of the published accounts of antipepsin.

The inhibiting action of sodium chlorid on pepsin has been studied particularly by Schütz ${ }^{\beta}$ and Levites. ${ }^{7}$ In a physicochemical study of

6. Schütz: Beitr. z. chem. Physiol. u. Path., 1904, v, 406.

7. Levites: Ztschr. f. physiol. Chem., xlviii, 187. 
the inhibiting effects of various salts on peptic digestion, Schütz arranged a table of their anions and cations in a decreasing order of their inhibiting action.

Levites, using other methods, came to practically similar conclusions, finding that the acid portion of the salt causes most active inhibition, that the metal portion was relatively slight, and that the salts of weak acids were more strongly inhibitory than those of strong acids.

We found, further, that if pepsin was dissolved in an acid solution strong enough to prevent inactivation by sodium chlorid, simple neutralization of this acidity alone (without addition of sodium chlorid) sufficed to cause inactivation. This is caused by the sodium chlorid formed from interaction of acid and alkali acting in a neutral

TABLE 2.-Protection of Pepsin by Hydrochloric Acid against Inactivation

\begin{tabular}{|c|c|c|c|c|c|c|c|}
\hline Tube* & $\begin{array}{c}\text { Pepsin in } \\
1 \text { c.c. } \mathrm{H}_{2} \mathrm{O} \\
\text { gm. }\end{array}$ & $\begin{array}{l}\text { Pepsin in } \\
1 \text { c.c. N/10 } \\
\mathrm{HCl} \\
\mathrm{gm} .\end{array}$ & $\begin{array}{l}\mathrm{N} / 10 \mathrm{HCl} \\
\text { c.c. }\end{array}$ & 10 Minutes & 30 Minutes & 18 Hours & 36 Hours \\
\hline $\begin{array}{l}1 \\
2 \\
3 \\
4 \\
5 \\
6\end{array}$ & $\begin{array}{l}0.0001 \\
0.0001 \\
0.0001 \\
\ldots \ldots \\
\ldots \ldots \\
\ldots \ldots\end{array}$ & $\begin{array}{l}\ldots \ldots \\
\ldots \ldots \\
\ldots \ldots \\
0.0001 \\
0.0001 \\
0.0001\end{array}$ & $\begin{array}{l}0.5 \\
1.0 \\
5.0 \\
0.5 \\
1.0 \\
5.0\end{array}$ & $\begin{array}{l}0 \\
0 \\
0 \\
+ \\
+ \\
+\end{array}$ & $\begin{array}{l}0 \\
0 \\
0 \\
+ \\
+ \\
+\end{array}$ & $\begin{array}{c}0 \\
0 \\
0 \\
++++ \\
+++++ \\
++++\end{array}$ & $\begin{array}{c}0 \\
0 \\
0 \\
++++ \\
++++ \\
++++\end{array}$ \\
\hline
\end{tabular}

* In each tube was placed carmin fibrin and 2.5 c.c. 0.85 per cent. sodium chlorid. All tubes were incubated for thirty minutes.

Sodium chlorid (2.5 c.c. in 0.85 per cent. solution) prevents pepsin in solution in water from digesting carmin fibrin, in spite of the subsequent addition (in excess) of $\mathrm{N} / 10$ hydrochloric acid. Pepsin dissolved in N/10 hydrochloric acid is not prevented from acting by sodium chlorid.

solution to cause inactivation, the ferment having been placed in a neutral solution by this same interaction. This last fact-the inactivation of pepsin-by the neutralization of acid pepsin, forms the basis for this report, particularly the significance of this finding in the neutralization of gastric juice.

Gastric juice was obtained from Pawlow dogs and by aspiration of the human fasting stomach in seven cases:

Normal stomach.

Alcoholic gastritis.

Hyperacidity - two cases.

Ulcer.

Carcinoma-two cases.

Peptic digestion was estimated by nitrogen determinations of the noncoagulable proteid of inactivated beef serum, after the method described in the work on antipepsin. 
The following cases will serve as illustrations:

CASE 1.-B. S., male medical ward. Clinical diagnosis, gastric ulcer. Aspiration of fasting stomach: 20 c.c. bile-stained fluid, free hydrochloric acid 6 , total acid 20 .

Table 3.-Inactivation of Pepsin by Neutralization of Gastric Juice from Ulcer Patient

\begin{tabular}{|c|c|c|c|c|c|c|}
\hline Flask & $\begin{array}{c}\text { Gastric } \\
\text { Juice } \\
\text { c.c. }\end{array}$ & $\begin{array}{c}\text { Neutral- } \\
\text { ized } \\
\text { Gastric } \\
\text { Juice }\end{array}$ & $\begin{array}{l}\text { Neutral- } \\
\text { ized and } \\
\mathrm{NaCl} \\
\text { Added }\end{array}$ & $\begin{array}{c}\mathrm{N} / 10 \\
\mathrm{HCl} \\
\text { c.c. }\end{array}$ & $\begin{array}{c}\text { Beef } \\
\text { Serum } \\
\text { c.c. }\end{array}$ & Kjeldah \\
\hline $\begin{array}{l}1 \\
2 \\
3\end{array}$ & $\begin{array}{l}0.5 \\
0.5 \\
0.5\end{array}$ & $\begin{array}{l}0 \\
+ \\
+\end{array}$ & $\begin{array}{l}0 \\
0 \\
+\end{array}$ & $\begin{array}{l}5 \\
5 \\
5\end{array}$ & $\begin{array}{l}5 \\
5 \\
5\end{array}$ & $\begin{array}{r}34.0 \\
3.5 \\
2.8\end{array}$ \\
\hline
\end{tabular}

In Flask 1, the unchanged juice gave a digestion figure of 34 (Kjeldahl), while Flask 2, in which juice had been neutralized with tenth-normal sodium hydroxid, no digestion occurs (3.5 Kjeldahl resulting from control normal serum). In each flask the later addition of 5 c.c. hydrochloric acid fails to reactivate pepsin. In other words, the ferment is permanently inactivated (deviated), and prevented from causing further digestion by the simple neutralization of the gastric juice.

CASE 2.-I. S. Male medical ward. Clinical diagnosis, carcinoma. Aspiration of fasting stomach: 12 c.c. viscid yellow-green fluid; free hydrochloric acid, 0 ; total acid, 40 .

Table 4.-Inactivation of Pepsin by Neutralization of Gastric Juice in Carcinoma of THE STOMACH

\begin{tabular}{c|c|c|c|c|c|c|c}
\hline \hline Flask & $\begin{array}{c}\text { Gastric } \\
\text { Juice } \\
\text { c.c. }\end{array}$ & $\begin{array}{c}\text { Neutral- } \\
\text { ized } \\
\text { Juice }\end{array}$ & $\begin{array}{c}\text { Neutral- } \\
\text { ized and } \\
\text { NaCl } \\
\text { Added }\end{array}$ & $\mathrm{NaCl}$ & $\begin{array}{c}\text { N/10 } \\
\mathrm{HCl} \\
\text { c.c. }\end{array}$ & $\begin{array}{c}\text { Beef } \\
\text { Serum } \\
\text { c.c. }\end{array}$ & Kjeldahl \\
\hline & 0.5 & 0 & 0 & 0 & 5 & 5 & 18.8 \\
2 & 0.5 & + & 0 & 0 & 5 & 5 & 3.0 \\
3 & 0.5 & + & + & 0 & 5 & 5 & 4.6 \\
4 & 0.5 & 0 & 0 & + & 5 & 5 & 17.7 \\
\hline
\end{tabular}

This case is similar to the preceding, showing in addition in Flask 4 the inability of sodium chlorid alone to deviate ferment.

Although seven cases constitute a minimum number on which to draw conclusions, still the findings were so uniformly positive and so completely in accord with the earlier work, that it seemed unnecessary to gather a larger series. They showed constantly that the neutralization of gastric juice results in complete inhibition of peptic action even after the addition of hydrochloric acid in excess, and that the inhibition of pepsin is due to sodium chlorid acting in a neutral medium. 
What is the mechanism of the inhibition of pepsin by sodium chlorid? While there is no direct experimental answer to this question, the explanation, I believe, rests on the modern conception of ferment action, as described by Michaelis, ${ }^{8}$ Loeb, ${ }^{9}$ and others.

Michaelis, with the aid of electrical conductivity readings, found that the proteolytic action of pepsin depends on its electrolytic dissociation, and that only the positively charged pepsin ions (cations) are capable of proteolytic digestion.

On the addition of hydrochloric acid to neutral pepsin, a salt is formed which may dissociate in one or both of two ways:

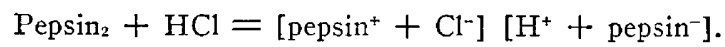

Of these only the cation pepsin $\left(p e p \sin ^{+}\right)$is active. If, however, sodium chlorid be added in place of acid, a new salt is formed, sodium pepsin, which is proteolytically inactive because of the preponderance of inactive anions and absence of active cations:

Pepsin $z+\mathrm{NaCl}=\left[\mathrm{Na}^{+}+\right.$pepsin- $]\left[\right.$pepsin $\left.{ }^{+}+\mathrm{Cl}^{-}\right]$.

Has this phenomenon of pepsin inactivation any clinical application? If so, its significance would lie in the ability to adopt measures whereby the stomach acid could be completely neutralized and the neutral reaction continuously maintained, and also that the newly formed and secreted acid could be immediately and continuously bound with alkali, as soon as it was formed. If this could be accomplished, the pepsin set free by neutralization, as well as the newly secreted pepsin, would be bound by inhibiting sodium chlorid and permanently inactivated and deviated. As a result, peptic activity would be destroyed for a period of time equal to the continuance of the neutral reaction, a condition similar to achylia gastrica. In fact, the findings would be those of a temporary achylia, with neutral or alkaline reacting stomach contents and total absence of peptic digestion.

Under what conditions would such a temporary achylia be desirable? First, as a prophylactic measure, to prevent the formation of gastric or duodenal ulcer. Second to facilitate the healing of ulcer by removing the factor which, next to mechanical trauma, is probably of greatest importance in the continuance and progression of chronic ulcer. Therefore, in simple hyperacidity, in hypersecretion from whatever cause, in motor insufficiency with continuous secretion, in pylorospasm with hyperacidity and hypersecretion, in chronic ulcer, in gastroenterostomy to prevent the formation of jejunal ulcer, neutralization with peptic inactivation might be desired.

8. Michaelis and Davidsohn: Bioch. Ztschr., 1911, xxxvi, 280.

9. Loeb: Bioch. Ztschr., 1909, xix, 534. 
The present methods of treatment of these hyperacid conditions with alkaline substances, attempt to control or lessen the chemical discomfort and to reduce the degree of acidity-particularly of the free hydrochloric acid. While such methods are of highest importance, it is evident, from these experiments, that the ideal of alkaline treatment is not merely the lessening of gastric acidity, but, of probably far greater importance, the complete and continuous neutralization of the acid contents of the stomach-to the end that pepsin be deviated and peptic digestion prevented.

The endeavor to demonstrate and maintain complete, continuous neutralization of the gastric contents is being made at the present time. By means of a Rehfuss stomach tube, kept constantly in the stomach for days at a time, fractional aspirations and readings of the stomach contents can be made at any time, and the degree of acidity or alkalinity measured. By this means, the effect of various foods, methods and time of feeding, neutralizing strength of various alkaline substances, can be directly measured and recorded. The results from these investigations are too few to warrant publication at this time. In general, however, it may be said that by the use and combination of certain of these alkaline substances, combined with certain foods and methods of feeding, continuous, complete neutralization of the stomach contents can be demonstrated and maintained.

\section{CONCLUSIONS}

1. Sodium chlorid will prevent pepsin in aqueous solution from digesting protein. This confirms the work of Schütz and Levites on the inhibiting action of various salts on peptic digestion.

2. The inhibition of pepsin by sodium chlorid, together with the ability of animal serum to deviate pepsin (described in an earlier paper), is responsible for most, if not all, of the published accounts of antipepsin.

3. The inhibition of pepsin by sodium chlorid is permanent, the inactivated ferment failing of reactivation by the subsequent addition of hydrochloric acid. 'The inactivation may be prevented, however, by dissolving the ferment in dilute hydrochloric acid.

4. Neutralization of pepsin dissolved in hydrochloric acid alone (without the addition of sodium chlorid) inhibits the ferment by the sodium chlorid formed from union of alkali and acid, acting in a neutral solution. Complete neutralization of the gastric juice causes similar pepsin inactivation.

5. The inactivation of pepsin by complete and continuous neutralization of gastric juice is indicated in the treatment of various diseases 
of the stomach in which temporary inhibition of peptic digestion is desired. This is particularly true in the prevention and cure of chronic gastric ulcer. By the use of certain foods, methods and time of feeding, and various alkaline substances, complete and continuous neutralization can be obtained.

104 South Michigan Boulevard. 